\title{
Rate of gonadotrophin-induced abnormalities in mouse ova is related to the site of hormone administration
}

\author{
E. Lehtonen and R. Kankondi* \\ Department of Pathology, University of Helsinki, Haartmaninkatu 3, SF-00290 Helsinki, Finland
}

\begin{abstract}
Summary. Adult female mice, regardless of the stage of the oestrous cycle, were superovulated with PMSG and hCG. Ovulated oocytes were recovered $20-22 \mathrm{~h}$ after hCG and fertilized ova $72-74 \mathrm{~h}$ after hCG. Compared with the controls, the gonadotrophin treatment increased the mating rate of the females, and the incidence of abnormal ova. Regardless of the site of gonadotrophin injections, the numbers of ova were equal, but the proportion of abnormal eggs in mice injected intraperitoneally was significantly higher than in mice injected subcutaneously.
\end{abstract}

\section{Introduction}

Gonadotrophin treatment of female mice results in ovulation of large numbers of oocytes. As compared with spontaneous ovulation, superovulation is associated with a lower rate of fertilization and a higher loss of embryos during pregnancy (Gates, 1956, 1971; Fowler \& Edwards, 1957, 1960; Edwards \& Gates, 1959; Allen \& McLaren, 1971; Beaumont \& Smith, 1975). Little is known about the mechanisms involved, and attempts to synchronize exogenous administration of gonadotrophins with endogenous hormonal events have not resulted in better embryo survival (Beaumont \& Smith, 1975).

We have performed a quantitative and morphological analysis on superovulated ova of mice to determine how route of gonadotrophin treatment affects the normality of the resulting oocytes and embryos.

\section{Materials and Methods}

Virgin female mice of the inbred CBA-T ${ }_{6} \mathrm{~T}_{6}$ strain, aged 10-12 weeks, were used. The animals were kept in a room with alternating periods of $16 \mathrm{~h}$ of light and $8 \mathrm{~h}$ of darkness (lights on 08:00 h). All animals, those treated with gonadotrophin and the untreated controls, were picked randomly regardless of the stage of the oestrous cycle. Food and water were given ad libitum.

For superovulation, mice were injected with 5i.u. PMSG (Gestyl; N.V. Organon, Oss, The Netherlands; or Sigma Chemical Co., St Louis, MO, U.S.A.) followed 48 h later by 5 i.u. hCG (Pregnyl; N.V. Organon). The gonadotrophins were diluted in $\mathrm{NaCl}$-phosphate buffer $(140 \mathrm{~mm}-\mathrm{NaCl}, 10 \mathrm{~mm}$-sodium phosphate, $\mathrm{pH} 7 \cdot 2)$ and administered intraperitoneally or subcutaneously. The injections were timed between 10:00 $\mathrm{h}$ and 12:00 h.

At $7.9 \mathrm{~h}$ after hCG each female was caged with one fertile male overnight. Mating was confirmed $13-15 \mathrm{~h}$ later by the presence of a vaginal plug. The numbers of superovulated oocytes were determined separately for two groups of females: those which were caged with a male but did not mate, and those which were not caged with a male.

Oocytes were recovered $22-24 \mathrm{~h}$ after hCG by dissecting the oviducts and ova from the mated females $72-74 \mathrm{~h}$ after hCG by flushing the uteri and dissecting the oviducts in medium (Lehtonen, 1985). Oocytes were characterized as cumulus-covered or cumulus-free and as normal or abnormal. Hyaluronidase was used for removing cumulus cells (Lehtonen, 1985). Spherical oocytes with one polar body and one pronucleus were considered normal. Oocytes with any signs of fragmentation, membrane blebbing or degeneration were considered abnormal. Embryos recovered from mated females were evaluated similarly: distorted, fragmented, degenerated, and cleavage-arrested ova were considered abnormal.

All the statistical analyses were performed using Student's $t$ test.

*Present address: College of Veterinary Medicine, Hämeentie 57, SF-00550 Helsinki, Finland. 


\section{Results}

Influence of gonadotrophin treatment on quantity of oocytes

All 51 gonadotrophin-treated animals examined 22-24 h after hCG possessed recently ovulated oocytes. The mean number of oocytes in females that were caged with a male but did not mate was $31.7 \pm 6 \cdot 8$; treated females not subjected to pairing yielded $35 \cdot 5 \pm 7 \cdot 0$ oocytes (Table 1). This difference is not significant $(P>0 \cdot 1)$. There was no difference $(P>0 \cdot 1)$ between the mean numbers of ova after subcutaneous and intraperitoneal injections. Nearly all $(98 \%)$ of the oocytes were surrounded by cumulus cells, while $2 \%$ were free of cumulus; the site of injection did not affect this relationship, and there was no difference between the paired and non-paired females (Tables 1 and 2).

\section{Influence of site of gonadotrophin administration on the proportion of abnormal oocytes}

The proportions of normal and abnormal oocytes are presented in Table 1. After subcutaneous administration of gonadotrophins, $7.5 \%$ of the cells in paired females were cumulus-covered but abnormal, and after intraperitoneal administration, $14.5 \%(P<0.01)$. This difference in incidence of oocyte abnormality was similar in the unpaired females (Table 1).

\section{Influence of gonadotrophin treatment on mating and fertilization frequency}

Superovulation caused nearly a 3 -fold increase in mating frequency, but a slight reduction in the relative proportion of pregnancies on Day 13 post coitum (Table 2).

Table 1. Unfertilized oocytes in gonadotrophin-treated females $22-24 \mathrm{~h}$ after hCG

\begin{tabular}{|c|c|c|c|c|c|c|c|c|}
\hline \multirow[b]{2}{*}{ Female } & \multirow{2}{*}{$\begin{array}{l}\text { Site of } \\
\text { injection }\end{array}$} & \multirow{2}{*}{$\begin{array}{l}\text { No. of } \\
\text { mice }\end{array}$} & \multicolumn{2}{|c|}{$\begin{array}{c}\text { No. of } \\
\text { oocytes/mouse }\end{array}$} & \multicolumn{2}{|c|}{$\begin{array}{l}\text { Cumulus } \\
\text { covered }(\%)\end{array}$} & \multicolumn{2}{|c|}{$\begin{array}{l}\text { Cumulus } \\
\text { free }(\%)\end{array}$} \\
\hline & & & Mean \pm s.d. & Range & Normal & Abnormal & Normal & Abnormal \\
\hline Paired & s.c. & 19 & $31 \cdot 6 \pm 7 \cdot 4$ & $18-44$ & $90 \cdot 5$ & $7 \cdot 5$ & $1 \cdot 5$ & 0.5 \\
\hline Paired & i.p. & 16 & $31.9 \pm 6.2$ & $16-40$ & $83 \cdot 7$ & $14 \cdot 5$ & $1 \cdot 4$ & 0.4 \\
\hline Paired & Total & 35 & $31.7 \pm 6.8$ & $16-44$ & $87 \cdot 1$ & $11 \cdot 0$ & $1 \cdot 4$ & 0.5 \\
\hline Unpaired & s.c. & 9 & $35 \cdot 6 \pm 7 \cdot 1$ & $19-50$ & $89 \cdot 2$ & $8 \cdot 0$ & 1.8 & $1 \cdot 0$ \\
\hline Unpaired & i.p. & 7 & $35.3 \pm 7.9$ & $18-56$ & $80 \cdot 8$ & $16 \cdot 4$ & $1 \cdot 8$ & 1.0 \\
\hline Unpaired & Total & 16 & $35.5 \pm 7.5$ & $18-56$ & $85 \cdot 0$ & $12 \cdot 2$ & 1.8 & 1.0 \\
\hline
\end{tabular}

Ovulation was induced by subcutaneous (s.c.) or intraperitoneal (i.p.) injections of PMSG and hCG. Oocytes were harvested from females that were paired with males but had not mated and from females that were not paired.

Table 2. Influence of gonadotrophin treatment on mating and fertilization frequency

\begin{tabular}{lccc}
\hline & $\begin{array}{c}\text { No. of } \\
\text { pairings }\end{array}$ & $\begin{array}{c}\% \\
\text { Mating }\end{array}$ & $\begin{array}{c}\% \\
\text { Pregnant* }\end{array}$ \\
\hline Treated & 90 & $60 \cdot 3$ & 95 \\
Untreated & 148 & $19 \cdot 6$ & 100 \\
\hline
\end{tabular}

*On Day 13 post coitum. 
Table 3. Influence of gonadotrophin treatment on the quantity and quality of ova at $72-74 \mathrm{~h}$ after hCG

\begin{tabular}{|c|c|c|c|c|c|c|}
\hline & \multirow{2}{*}{$\begin{array}{l}\text { No. of } \\
\text { mice }\end{array}$} & \multicolumn{3}{|c|}{ No. of ova } & \multicolumn{2}{|c|}{ Quality of ova } \\
\hline & & Total & Mean \pm s.d. & Range & Normal & Abnormal \\
\hline Treated* & 18 & 318 & $17 \cdot 7 \pm 5 \cdot 6$ & $6-24$ & $80 \cdot 7 \%$ & $19 \cdot 3 \%$ \\
\hline Untreated & 17 & 108 & $6.4 \pm 1.6$ & $3-8$ & $91 \cdot 4 \%$ & $8 \cdot 6 \%$ \\
\hline
\end{tabular}

*Seven of the treated mice were injected i.p. and 11 s.c.

Table 4. Influence of site of gonadotrophin treatment on proportions of normal and abnormal ova at $72-74 \mathrm{~h}$ after $\mathrm{hCG}$

\begin{tabular}{|c|c|c|c|c|c|}
\hline \multirow{2}{*}{$\begin{array}{l}\text { Site of } \\
\text { injection }\end{array}$} & \multirow{2}{*}{$\begin{array}{l}\text { No. of } \\
\text { ova }\end{array}$} & \multirow{2}{*}{$\begin{array}{c}\% \\
\text { Normal* }\end{array}$} & \multicolumn{3}{|c|}{ Abnormal (\%) } \\
\hline & & & Total & Distorted $\dagger$ & 1-cell \\
\hline s.c. & 182 & $82 \cdot 0$ & $18 \cdot 0$ & $15 \cdot 5$ & $2 \cdot 5$ \\
\hline i.p. & 130 & $77 \cdot 1$ & 22.9 & $20 \cdot 0$ & $2 \cdot 9$ \\
\hline
\end{tabular}

*Embryos consisting of 2-8 spherical blastomeres.

$\uparrow$ Fragmented or degenerating.

Table 5. Influence of gonadotrophin treatment on proportions of different cleavage stages and abnormal ova at $72-74 \mathrm{~h}$ after $\mathrm{hCG}$

\begin{tabular}{|c|c|c|c|c|c|c|}
\hline & \multirow{2}{*}{$\begin{array}{c}\text { No. of } \\
\text { ova }\end{array}$} & \multicolumn{5}{|c|}{ Developmental stage (\%) } \\
\hline & & 1-cell & 2-cell & 3-4-cell & 5-8-cell & Distorted* \\
\hline Treated & 126 & $3 \cdot 2$ & $5 \cdot 6$ & $42 \cdot 0$ & $35 \cdot 7$ & $13 \cdot 5$ \\
\hline Untreated & 45 & $2 \cdot 2$ & $11 \cdot 1$ & $66 \cdot 7$ & $13 \cdot 3$ & $6 \cdot 7$ \\
\hline
\end{tabular}

*Fragmented or degenerating ova.

\section{Influence of gonadotrophin treatment on quantity and quality of ova 72-74 h after hCG}

Superovulation resulted in a 3-fold increase in the mean number of ova. The variation in the number of ova recovered from the treated females was significantly greater than that observed for the untreated females (Table 3). Compared with the figures at 22-24 h after hCG (Table 1) there was a $45 \cdot 2 \%$ reduction in the number of ova by $72-74 \mathrm{~h}$ after hCG (Table 3 ). The proportion of abnormal ova in the superovulated females was more than twice that in the non-treated controls (Table 3).

Influence of site of gonadotrophin administration on the proportion of abnormal ova 72-74h after $h C G$

At $72-74 \mathrm{~h}$ after hCG administration by the subcutaneous or intraperitoneal route, $18 \%$ and $22.9 \%$ respectively, of the ova were abnormal (Table 4 ). This difference is relatively small. However, in animals injected subcutaneously, the proportions of abnormal eggs were consistently smaller than in animals injected intraperitoneally $(P<0.005)$. Compared with the figures at 22-24 $\mathrm{h}$ after hCG (Table 1), the difference between the two routes of gonadotrophin administration appears to diminish by $72-74 \mathrm{~h}$ after hCG. 
In a separate series of experiments, proportions of different cleavage stages in superovulated females at $72-74 \mathrm{~h}$ after hCG were compared with those in untreated females paired with males simultaneously. On average, fertilization took place slightly earlier and/or cleavage occurred more rapidly (Allen \& McLaren, 1971) in the gonadotrophin-treated group (Table 5). The proportions of abnormal ova and 1-cell ova in this series were similar to those presented in Table 4 . Two-cell ova found $72-74 \mathrm{~h}$ after hCG should obviously be considered as having arrested cleavage and abnormal (Table 5).

\section{Discussion}

The oocyte yields recovered after gonadotrophin treatment were as expected. Gonadotrophin treatment of adult mice results in a 3-fold increase in the number of ovulated oocytes (Fowler \& Edwards, 1957, 1960; Edwards \& Gates, 1959; Edwards et al., 1963; Runner \& Palm, 1953; Lin \& Bailey, 1965; Beaumont \& Smith, 1975; Ito et al., 1981). In this study, oocytes were not collected from spontaneously ovulating females, but at $72-74 \mathrm{~h}$ after hCG the number of ova in superovulated females was about 3 times that of untreated females.

Several attempts have been made to maximize superovulation yields (Edwards et al., 1963; Gates, 1971; Beaumont \& Smith, 1975). Beaumont \& Smith (1975) synchronized the administration of gonadotrophins with the innate oestrous cycle by timing the administration of hCG to coincide with the endogenous LH surge, which resulted in a 2-fold increase in the number of ova on Day 2 post coitum. In the present study we found a 3-fold increase in the number of oocytes at the same developmental stage ( $72-74 \mathrm{~h}$ after hCG). Compared with the result of Beaumont \& Smith (1975), this increase is surprisingly high, as the females were picked randomly regardless of the stage of oestrous cycle. One possible explanation for this is a difference between the mouse strains used (Lin \& Bailey, 1965; McLaren, 1967; Luckett \& Mukherjee, 1986). Alternatively, the most responsive stage of the oestrous cycle to the superovulatory treatment has not yet been identified.

In this study, the gonadotrophin-treated females that were paired but did not mate produced slightly lower numbers of oocytes than did non-paired females. This is not surprising, as both the number of oocytes and the mating activity in superovulated females are probably similarly connected with the stage of the innate oestrous cycle.

In connection with superovulation, there is an increase in fragmented, degenerate and denuded oocytes (Beaumont \& Smith, 1975; Miller \& Armstrong, 1981a, b; Walton \& Armstrong, 1981; Walton et al., 1983; Moor et al., 1985; present study). The mechanisms by which superovulation increases the incidence of abnormal ova are not clear. Three explanations have been put forward. Degeneration and fragmentation take place gradually in ageing ova. Any abnormality in the cumulus-free oocytes could result from ageing as they were presumably ovulated due to the PMSG injection. Second, at $72-74 \mathrm{~h}$ in our study a considerable proportion of the ova appeared to have been activated, but were undergoing degeneration and fragmentation. It is therefore possible that in some ova degenerative changes occur as a result of failure in fertilization (Walton et al., 1983), possibly owing to imbalance in the concentrations of oestrogen and progesterone (Fowler \& Edwards, 1960; Harrington, 1965; Jutaro et al., 1982). Tesh (1966) and Fujimoto et al. (1974) have proposed that gonadotrophin treatment produces genetic defects in the ova.

At present it is not possible to differentiate between the above possibilities. However, administration of gonadotrophins intraperitoneally increases the proportion of abnormal ova more than does subcutaneous administration. To our knowledge, this aspect has not been thoroughly studied, although Gates (1971) noted that virtually no difference could be detected between the two routes of gonadotrophin administration, and that intraperitoneal injection has been preferred in the interest of convenience. The mechanisms by which the intraperitoneal route of gonadotrophin treatment increases the incidence of abnormality are not known, but our results suggest that subcutaneous rather than intraperitoneal administration of gonadotrophins should be used for superovulation of mice. 
We thank Ms Ulla Kiiski and Ms Paula Turkkelin for expert technical assistance. This study was supported by the Medical Research Council of Academy of Finland, the Finnish Cancer Research Fund, the Sigrid Jusélius Foundation, and the Ministry of Foreign Affairs, Finland.

\section{References}

Allen, J. \& McLaren, A. (1971) Cleavage rate of mouse eggs from induced and spontaneous ovulation. $J$. Reprod. Fert. 27, 137-140.

Beaumont, M.H. \& Smith, F.A. (1975) Embryonic mortality during pre- and post-implantation periods of pregnancy in mature mice after superovulation. $J$. Reprod. Fert. 45, 437-448.

Edwards, R.G. \& Gates, A.H. (1959) Timing of the stages of maturation divisions, ovulation, fertilization and the first cleavage of eggs of adult mice treated with gonadotrophins. J. Endocr. 18, 292-304.

Edwards, R.G., Wilson, E.D. \& Fowler, R.E. (1963) Genetic and hormonal influences on ovulation and implantation in adult mice treated with gonadotrophins. J. Endocr. 26, 389-399.

Fowler, R.E. \& Edwards, R.G. (1957) Induction of superovulation and pregnancy in mature mice by gonadotrophins. J. Endocr. 15, 374-384.

Fowler, R.E. \& Edwards, R.G. (1960) Effects of progesterone and oestrogen on pregnancy and embryonic mortality in adult mice following superovulation and pregnancy in mature mice by gonadotrophin. $J$. Endocr. 20, 1-8.

Fujimoto, S., Pahlavan, N. \& Dukelow, W.R. (1974) Chromosomal abnormalities in rabbit preimplantation blastocysts induced by superovulation. $J$. Reprod. Fert. 40, 177-181.

Gates, A.H. (1956) Viability and developmental capacity of eggs from immature mice treated with gonadotrophins. Nature, Lond. 177, 754-755.

Gates, A.H. (1971) Maximizing yield and developmental uniformity of eggs. In Methods in Mammalian Embryology, pp. 64-75. Ed. J. C. Daniel Jr. Freeman and Company, San Francisco.

Harrington, F.E. (1965) Transportation of ova and zygotes through the genital tract of immature mice treated with gonadotrophins. Endocrinology 77, 635-640.

Ito, M., Dowaki, M., Kashiwabara, H. \& Kamatsu, H. (1981) The time of ovulation in mice after superovulation and repeated superovulation. Jpn. J. Fert. Steril. 26, 20-26.

Jutaro, T., Kazumasa, H. \& Junji, M. (1982) Disturbance of pregnancy and the serum prolactin and progesterone levels in superovulated adult rat. Jpn. J. Anim. Reprod. 28, 59-66.
Lehtonen, E. (1985) A monoclonal antibody against mouse oocyte cytoskeleton recognizing cytokeratintype filaments. J. Embryol. exp. Morph. 90, 197-209.

Lin, P.T. \& Bailey, D.B. (1965) Differences between two inbred strains in ovulatory response to repeated administration of gonadotrophins. J. Reprod. Fert. 10, 253-259.

Luckett, D.C. \& Mukherjee, A.B. (1986) Embryonic characteristics in superovulated mouse strains. $J$. Hered. 77, 39-42, 1986.

McLaren, A. (1967) Factors affecting the variation in response of mice to gonadotrophic hormones. $J$. Endocr. 37, 147-1 54.

Miller, B.G. \& Armstrong, D.T. (1981a) Superovulatory doses of pregnant mare serum gonadotropin cause delayed implantation and infertility in immature rats. Biol. Reprod. 25, 253-260.

Miller, B.G. \& Armstrong, D.T. (1981b) Effects of a superovulatory dose of pregnant mare serum gonadotropin on ovarian function, serum estradiol, and progesterone levels and early embryo development in immature rats. Biol. Reprod. 25, 261-271.

Moor, R.M., Osborn, J.C. \& Crosby, I.M. (1985) Gonadotrophin-induced abnormalities in sheep oocytes after superovulation. J. Reprod. Fert. 74, $167-172$.

Runner, M.N. \& Palm, J. (1953) Transplantation and survival of ova of the mouse in relation to postovulatory age. J. exp. Zool. 124, 303-315.

Tesh, J.M. (1966) Effect of the time of insemination and superovulation on fertilization in the rabbit. $J$. Endocr. 35, xxviii, Abstr.

Walton, E.A. \& Armstrong, D.T. (1981) Ovarian function and early embryo development in immature rats given a superovulatory dose of PMSG, later neutralized by antiserum. Biol. Reprod. 25, 272-280.

Walton, E.A., Evans, G. \& Armstrong, D.T. (1983) Ovulation response and fertilization failure in immature rats induced to superovulate. J. Reprod. Fert. 67, 91-96. 